\title{
Update on HIV reservoirs
}

\author{
Sarah Palmer \\ From $16^{\text {th }}$ International Symposium on HIV and Emerging Infectious Diseases \\ Marseille, France. 24-26 March 2010
}

\begin{abstract}
Aim
During combination antiretroviral therapy, reduction of HIV-1 RNA levels to less than 50 copies $/ \mathrm{ml}$ is frequently achieved; however, residual low-level viremia has been detected using ultrasensitive assays. The source of persistent viremia is currently unknown: it could arise from ongoing cycles of replication in a sanctuary site, long-lived productively infected cells, and/or activation of viral expression from latently infected cell reservoirs. This presentation will discuss the characteristics and probable sources of persistent viremia.
\end{abstract}

\section{Materials and methods}

Insights into the source and dynamics of residual virus are determined using ultrasensitive assays for: 1) quantifying persistent viremia and 2) sequencing persistent HIV populations from plasma and cells.

\section{Results}

Using sensitive assays it has been shown that HIV persists for at least 7 years of therapy. The decay of persistent viremia in plasma of patients on suppressive therapy appears to be biphasic with short-lived cells contributing to the viremia initially followed by a second more constant release of virus from long-lived HIVinfected cells. An indicator that current treatment regimens halt ongoing viral replication is that intensifying a patient's treatment regimen does not result in a decrease in persistent viremia. Moreover, persistent viremia in patients under long-term treatment is genetically homogeneous and the viral population which rebounds during treatment interruption is also genetically homogeneous

\section{Discussion}

The genetic homogeneity of the viral populations in patients on suppressive thereapy indicates that persistent viremia arises from long-lived latently infected cells,

\footnotetext{
Virology Department, Swedish Institute for Infectious Disease Control and
} Karolinska Institute, Stockholm, Sweden such as resting memory CD4+ T-cells, tissue CD4+ $\mathrm{T}$-cells, tissue macrophages or stems cells, and reflects an evolutionary bottleneck during prolonged therapy. However, it is possible viral production may occur in such anatomical compartments as the gut or central nervous system where drug penetration is suboptimal.

Published: 11 May 2010

doi:10.1186/1742-4690-7-S1-I16

Cite this article as: Palmer: Update on HIV reservoirs. Retrovirology 2010

7(Suppl 1):116.
Submit your next manuscript to BioMed Central and take full advantage of:

- Convenient online submission

- Thorough peer review

- No space constraints or color figure charges

- Immediate publication on acceptance

- Inclusion in PubMed, CAS, Scopus and Google Scholar

- Research which is freely available for redistribution

Submit your manuscript at www.biomedcentral.com/submit
C Biomed Central 